International Journal of Osteoarchaeology

Int. J. Osteoarchaeol. (2011)

Published online in Wiley Online Library

(wileyonlinelibrary.com) DOI: 10.1002/oa.1293

\title{
A Roman Skeleton with Possible Treponematosis in the North-East of the Iberian Peninsula: A Morphological and Radiological Study
}

\author{
CARME RISSECH, ${ }^{a *}$ CHARLOTTE ROBERTS, ${ }^{b}$ XAVIER TOMÁS-BATLLE, ${ }^{\mathrm{c}}$ \\ XAVIER TOMÁS-GIMENO, ${ }^{\mathrm{d}}$ BENJAMIN FULLER, ${ }^{\mathrm{e}}$ PEDRO LUIS FERNANDEZ ${ }^{\mathrm{f}}$ AND \\ MIGUEL BOTELLA ${ }^{9}$ \\ a Unitat d'Antropologia Biològica, Dept. Biologia Animal, Vegetal i Ecologia, Universitat Autònoma de \\ Barcelona, Bellaterra, Barcelona, Spain \\ b Department of Archaeology, Durham University, Durham, UK \\ c Servei de Radiodiagnòstic, CDIC, Hospital Clínic, Universitat de Barcelona \\ d Servei de Radiodiagnòstic, Hospital St. Pau, Barcelona, Spain \\ e Department of Human Evolution, Max Planck Institute for Evolutionary Anthropology, Leipzig, Germany \\ f Servei d'Anatomia Patològica, Hospital Clínic, Universitat de Barcelona, Barcelona, Spain \\ g Lab. Antropología, Facultad de Medicina, Universidad de Granada, Granada, Spain
}

ABSTRACT The main goal of this paper is to describe and discuss pathological lesions observed in a Roman skeleton (between $2^{\text {nd }}$ and $3^{\text {rd }}$ century AD) from the north-east region of the Iberian Peninsula (St Nicasi 18-24 site. Gavà, Barcelona), which may be compatible with treponematosis. Most of the skeleton, with the exception of the neurocranium, was recovered. Only the left tibia was affected, whereas the rest of the recovered skeletal remains were unaffected. Macroscopic examination revealed a male individual between 25 and 30 years of age at death with a sabre-shaped left tibia. The proximal half of the diaphysis was pitted and the bone overall enlarged. The surface of the tibia showed occasional vascular impressions where, in some instances, small raised plaques of new bone appeared to bridge over them, specifically in the most affected area of the proximal half of the tibia. No destructive lesions were observed. Radiographic examination and gross inspection at the cross section of the tibia showed encroachment into the medullary cavity of coarse cancellous bone and cancellization of the cortex. The observed lesions indicate that the tibia was affected by a chronic infectious disease. Differential diagnoses were considered, and these included other infectious diseases, fibrous dysplasia, Paget's disease, chronic varicose ulcers affecting bone and trauma, with the conclusion that the disease affecting the tibia could have been treponematosis.

This could be significant in the history of the treponematoses being one of the oldest examples of treponematosis in pre-Columbian Europe. Copyright (C) 2011 John Wiley \& Sons, Ltd.

Key words: Treponematosis; syphilis; Late Roman period

\section{Introduction}

The treponematoses are a group of bacterial infections caused by spirochetes of the genus Treponema which belongs to the family Spirochaetaceae, and the order Spirocbaetales (Arrizabalaga, 1993). Clinically, four treponematoses are recognised: (i) pinta, which is endemic

\footnotetext{
* Corespondence to: Secc. d'Antropologia, Departament de Biologia Animal, Facultat de Biologia, Universitat de Barcelona, Avd. Diagonal, 645, 08028-Barcelona.

e-mail: carme.rissech@ub.edu
}

in the tropical zones of America; (ii) yaws, which is found in almost all humid tropical areas; (iii) endemic syphilis or bejel, which is found in the arid zones of Eurasia; and (iv) venereal syphilis, which may be congenital or acquired and is found all around the world regardless of climate. All of them, with the exception of pinta, can produce skeletal lesions, which correspond to the tertiary stage of the disease.

The origin and the geographical spread of the treponematoses have been the subject of numerous controversial debates. The debate mainly focuses on the presence and dating of skeletons with lesions 
consistent with venereal syphilis in the Old and New Worlds. The Columbian hypothesis maintains that venereal syphilis originated in America and was brought back to Europe by Christopher Columbus in $\mathrm{AD} 1493$ when he and his crew returned from his first voyage to the Americas (Williams et al., 1927; Harrison, 1959; Dennie, 1962; Goff, 1967; Crosby, 1969). Other theories maintain that it was already present in Europe before Columbus' voyage to the New World in AD 1492. Specifically, the pre-Columbian hypothesis states that venereal syphilis was present in Europe before 1493 but was unknown as it was not well differentiated clinically from leprosy (Holcomb, 1930, 1934, 1935; Cockburn, 1961; Hackett, 1963, 1967; Kampmeier, 1984). The hypothesis between these two 'extremes' postulates that treponemal disease had long been present both in the Old and New World. According to this last hypothesis, the four different forms of treponematosis originated from Treponema pallidum which then adapted to different environments (Hudson, 1958, 1963, 1965, 1968). Due to the fact that insufficient data have been obtained through documentary and ethnographic research to clarify the origin of this disease (Roberts, 1994), paleopathological research has become a useful tool in studying the origin of the treponematoses, providing direct evidence of the disease in combination with the environmental and social context of those affected. However, the debate continues.

The abundant skeletal evidence for the pre-Columbian presence of treponemal disease in the New World argues for an American origin, whereas the Old World evidence is scanty and sporadic. However, a number of medieval skeletons from England and Turkey predating 1492 show unambiguous skeletal lesions characteristic of treponematosis, reflecting the presence of treponematosis in Europe in the pre-Columbian period (Dawes and Magilton, 1980; Roberts, 1994; Stirland, 1994; Mays et al., 2003; Erdal, 2006). This paucity of evidence for pre-Columbian treponematosis in the Old World may be a consequence of the difficulty of recognizing the characteristic skeletal changes of treponematosis, which requires specialist training in paleopathology (Roberts, 1994). It is argued that in the New World, the number of researchers working with formal training in paleopathology is relatively higher than in the Old World; this means that more skeletal collections are examined by experienced researchers, a fact which may influence the numbers of identified skeletons with treponematosis (Roberts, 1994). However, in recent years, there have been improvements in training provision in the Old World (e.g. see Roberts, 2006).
Recently, with molecular studies thriving, research has focused on modern Treponema pallidum genes to try and elucidate the origin and spread of the treponematoses, but again data are controversial. The data obtained by Gray et al. (2006) indicate that sequences of Treponema pallidum subspecies pallidum appear to have too much variation to support the hypothesis of the evolution of venereal syphilis within the past 500 years. Contrary to this, observations made by Harper et al. (2007) suggest that venereal syphilis arose recently in human history ( 500 years ago) from a New World progenitor related to yaws. However, Mulligan et al. (2008) point out that this last study has limitations and argue that the phylogeny presented by Harper et al. (2007) does not show a significant structure. According to Mulligan et al. (2008) phylogenetic and network analyses presented by Harper and colleagues are contradictory in that the phylogeny supposedly supports the evolution of pallidum from endemicum, but the network is used to infer the origin of pallidum from New World pertenue strains. Part of the problem may be the fact that the phylogeny does not show significant structure and, when the tree is redrawn to show only branches with at least $50 \%$ bootstrap support, the pertenue cluster disappears and all three subspecies, plus the simian isolate, branch off the most basal branch simultaneously. This means that no evolutionary order can be inferred (Mulligan et al., 2008). Furthermore, ancient DNA analysis of skeletons with evidence of treponematosis has been generally unsuccessful to date (e.g. see Bouwman and Brrown, 2005; Von Hunnius et al., 2007), and therefore there does not at the current time seem to be much progress in determining the origin and evolution of the treponemal diseases through either modern or ancient molecular analysis. It is clear that Treponema pallidum is a difficult and complex pathogen in all senses, genetically, clinically and epidemiologically. Therefore, understanding the origin and evolution of the treponematoses is difficult, and a multidisciplinary approach is needed.

Thus, the main objective of this study is to describe and discuss a skeleton from the Late Roman period in the north-eastern region of the Iberian Peninsula which presents lesions suggestive of treponematosis.

\section{Material and methods}

The skeleton derives from an archaeological site located at St. Nicasi 18-24, a street in the centre of Gavà city (Barcelona, Spain) (Figure 1). Archaeological intervention was carried out as a rescue excavation by ArqueoCat SL at the end of 2005. The skeleton was 


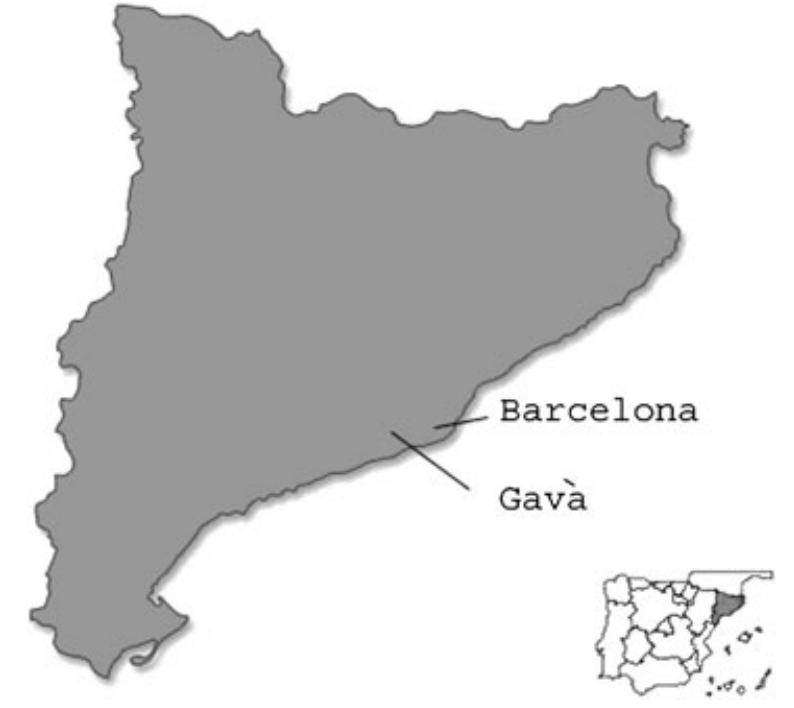

Figure 1. Map to show the location of the archaeological site of "St Nicasi 18-24" located in the centre of Gavà, Spain.

buried in a simple grave situated in the northern part of the site beneath the remains of houses and three other burials (two in simple graves and the third in a tile lined grave), all dated to the Roman period. The skeleton was radiocarbon dated to between the $2^{\text {nd }}$ and $3^{\text {rd }}$ century ury $\mathrm{AD}$, the date (see below) correlating with the statigraphic sequence of the site and the dating of associated materials (Prida-Trujillo, 2007). The Roman houses and the other three burials were dated to between the $4^{\text {th }}$ and $5^{\text {th }}$ centuries.

The skeleton's sex was estimated using the morphology of the innominate bones, the robustness of the skeleton and discriminant function analysis applied to measurements of the long bones and the innominates (Ferembach et al., 1980; Rissech and Malgosa, 1991, 1997; Alemán et al., 1997; Safont et al., 2000). Its age at death was estimated by dental wear, the morphology of the auricular surface, the pubic symphysis and the acetabulum (Lovejoy et al., 1985; Brothwell, 1987; Brooks and Suchey, 1990; Rissech et al., 2006, 2007).

The distribution of any abnormal bone formation and destruction was recorded macroscopically. Plain film radiography and computed tomography (CT) were applied to both tibiae in the Radiological Unit of St. Pau Hospital in Barcelona. A complete skeletal scan was also done of the whole skeleton using multidetector computed tomography (MDCT) in the Radiology Department of the Hospital Clinic in Barcelona. In the conventional radiographic study, digital mode was used. The radiographs were taken in two orthogonal projections, antero-posterior and mediolateral, with Philips Diagnost ${ }^{\circledR}$ medical radiological equipment, at 50 kilovolts $(\mathrm{kV})$ and 15 milliampere/second
(mAs) settings, with a focus-plate distance of $120 \mathrm{~cm}$. Digital radiological AGFA MultiSync LCD $18805 \mathrm{X}{ }^{\circledR}$ equipment was used for processing, adjusting the brightness and contrast of the image until maximum quality was achieved. For the CT study of both tibias, a Toshiba Asteion ${ }^{\circledR}$ equipment was used. The proximal halves of both tibiae were scanned in 23 five mm thick slices at intervals of $5 \mathrm{~mm}$, with an exposure time of $0.75 \mathrm{~s}$. Scans were done at $120 \mathrm{kV}$ and $150 \mathrm{mAs}$ via a bone filter with a final window adjustment of $\mathrm{WL}=1223$ and $\mathrm{WW}=2015$. For the MDCT study of the whole skeleton, a Somatom ${ }^{\circledR}$ Siemens-64-slices equipment was used. The remains were placed in normal anatomical position. First, a scan scout was taken of the remains, and then scan sequences of the whole body were carried out using helical acquisition. The scans were done at $120 \mathrm{kV}$, with a mAs which varied between 32 and 41 . A bone reconstruction algorithm and a wide window to accentuate the border of bony structures were used. The collimation factor was $0.6 \mathrm{~mm}$ with a scan section of $3 \mathrm{~mm}$, axial reconstruction of $0.6 \mathrm{~mm}$ and multiplanar reconstruction of $2 \mathrm{D}$ and $3 \mathrm{D}$ of $2 \mathrm{~mm}$. The images were enhanced to their maximum on a Siemens Wizard ${ }^{\circledR}$ console using Siemens Syngo ${ }^{\circledR}$ software. Surface rendering 3D images were obtained in different planes.

\section{Results: skeletal observations and dating}

\section{Skeletal preservation, age and sex estimation}

The skeletal remains were well preserved, with $70 \%$ of the skeleton present (Figure 2) although they wereslightly fragmented. The bone surfaces had slight post-depositional erosion. All the epiphyses were fused which indicated an adult individual. The morphology of the innominate bones, the robustness of the skeleton and discriminant function analysis applied to measurements of the long bones and innominate indicate that the individual was male. The morphology of the auricular surface, the pubic symphysis and the acetabulum, and dental wear and the lack of degenerative joint disease, would suggest that the individual is between 25 and 30 years old. Figure 3

\section{Pathological lesions}

Examination of the skeletal remains revealed that the left tibia was sabre shaped (Figure 4. and the diaphysis was thickened in its entire proximal half (Figures $4_{\lambda}$ and $5_{\text {K }}$, especially on its anterior aspect; this was due to bone deposition on the anterior tibial crest, resulting in its 

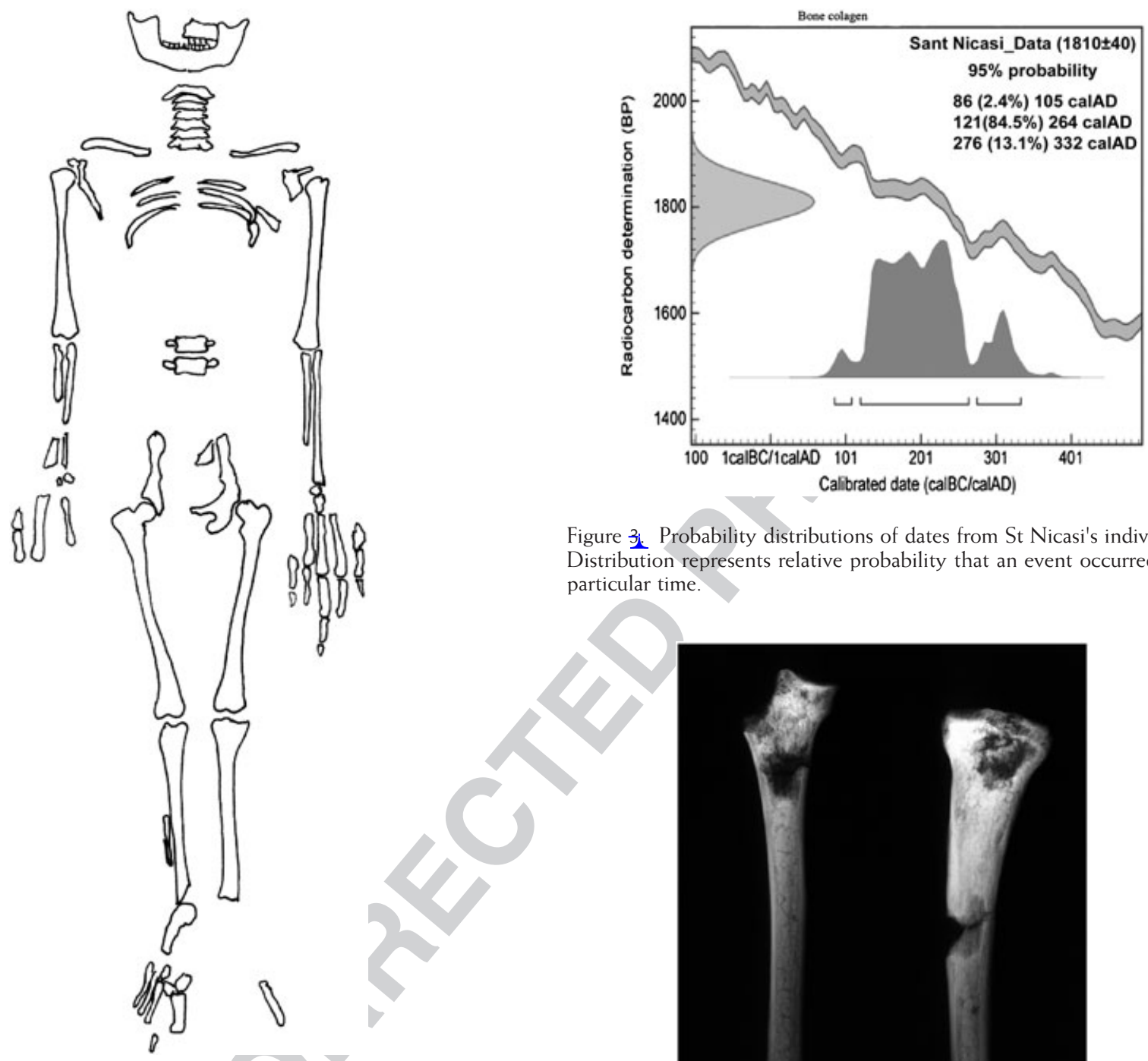

Figure 3. Probability distributions of dates from St Nicasi's individual. Distribution represents relative probability that an event occurred at a particular time.

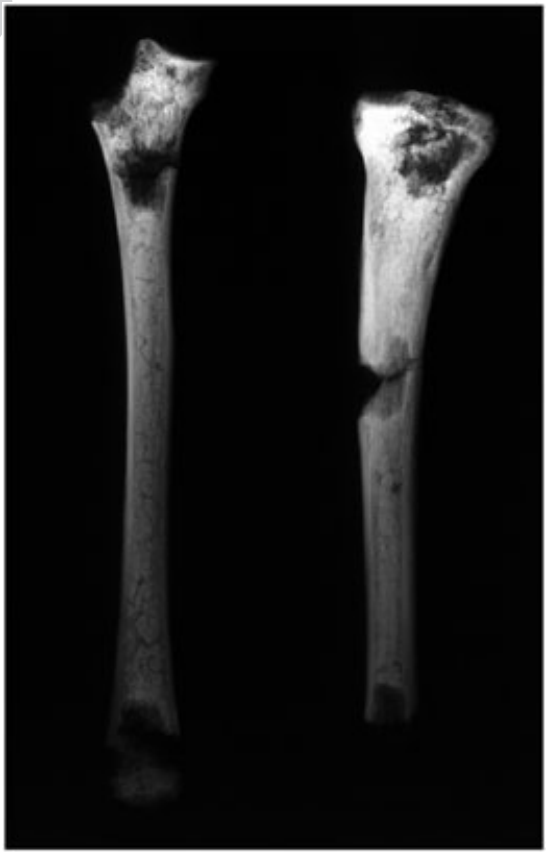

sabre-shaped morphology. The external cortical surface was irregularly thickened, with an enlarged appearance. Pitted areas and vascular grooves were consistently

F6 present (Figure 6). In fact, all the surface of the tibia showed occasional scattered, shallow grooves which appeared to represent impressions of superficial blood vessels. In some instances, small raised plaques of new bone appeared to bridge over small vessels, specifically in the most affected area, the proximal half of the tibia (Figure 6). Most deposits were well remodelled with the exception of the small raised plaques of new bone. There were no destructive lesions.

A plain film radiograph shows a vertical medullary F7 F8 cavity (Figure 7). MDCT analyses (Figure 8), and macroscopic examination of both post-depositional F9 breaks (Figure 9) and cross sections of both tibiae F10 (Figure 10), showed encroachment into the medullary

Copyright (C) 2011 John Wiley \& Sons, Ltd. 


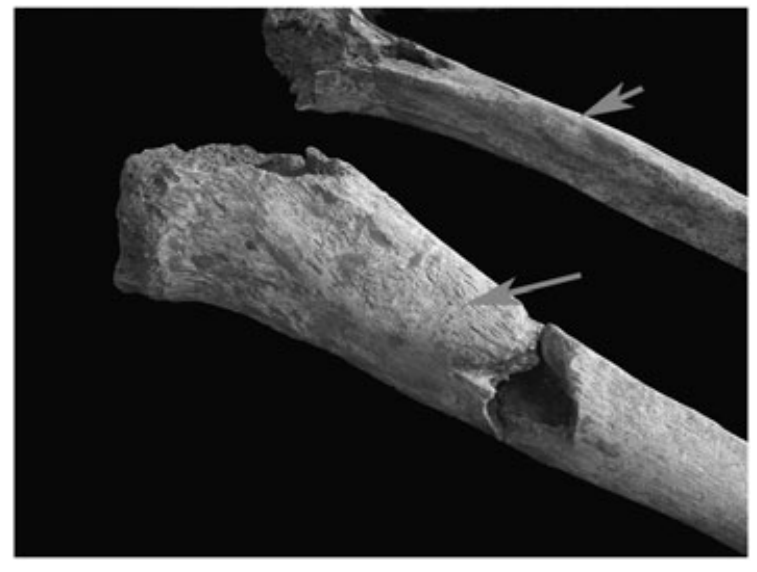

Figure $5_{\boldsymbol{\alpha}}$ Photograph showing the difference between the tibiae. The anterior surface of the proximal diaphysis of the left tibia is enlarged due to deposition of subperiosteal new bone.

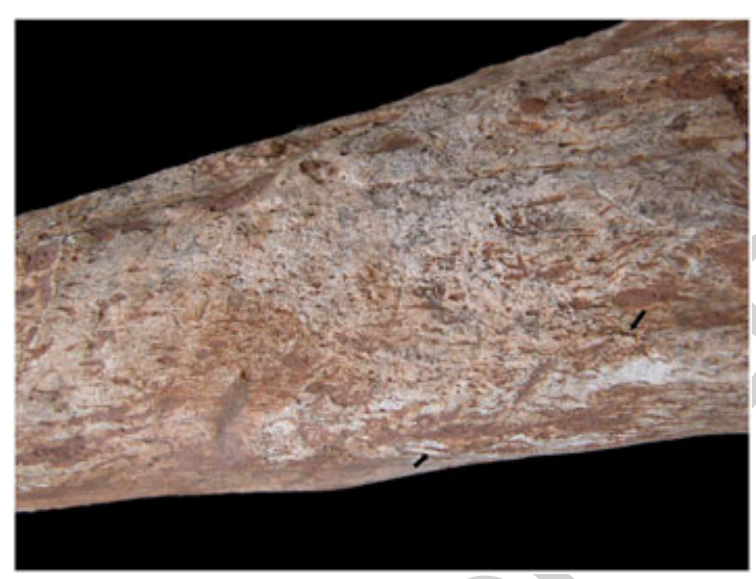

Figure 6. Detail of new bone formation on medial surface of the left tibia of the St Nicasi's individual. Arrows show some of the small raised plaque bridges. They appear to have spanned a small blood vessel whose course can be traced by a visible channel above and to the right of the bony bridge. This figure is available in colour online at wileyonlinelibrary.com/journal/oa.

The left part of the maxilla and the entire mandible are the only remains of the skull that were present. No other alterations that could be related to those found in the tibia were observed in the rest of the skeleton.

\section{Dating}

A radiocarbon determination was carried out by Beta analytic Inc. (Miami, USA) in 2007. The sample of the St Nicasi's skeleton was processed according to the methods outlined in Mook and Streurman (1983) and dated as described by Beukens et al. (1986). The result is a conventional radiocarbon age, corrected for

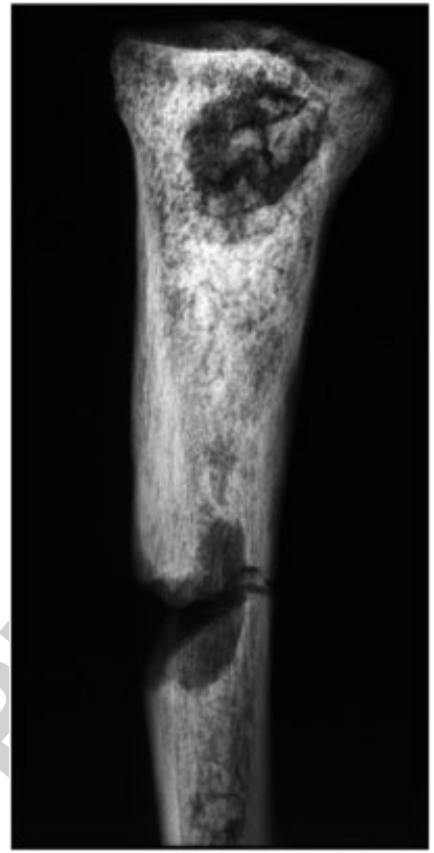

Figure 7. Radiograph of the proximal half of the left tibia showing a vertical medullary cavity.

isotopic fractionation (Stuiver and Polach, 1977). Using the maximum intercept method of Stuiver and Reimer (1986) and the calibration data of Stuiver et al. (1998), the date calibrates to AD 121 - 264 (at 85\% confidence; Beta-231225; 1810 $\pm 40 \mathrm{BP}$ ). The distribution of probability of the calibrated date is shown in Figure $3_{\lambda}$ (Stuiver and Reimer, 1993).

Because a substantial marine component to the diet may affect radiocarbon dates (Arneborg et al., 1999), carbon and nitrogen stable isotope levels were measured in order to assess the presence of a marine component in the diet of this individual. These levels were determined in 2008 by B.F. at the Max Planck Institute, Leipzig, Germany, using methods described by Richards and Hedges (1999). The obtained value for $\partial^{13} \mathrm{C}$ was -18.66 and for $\partial^{15} \mathrm{~N}$ was 10.14 . A $\partial{ }^{13} \mathrm{C}$ value of -18.66 is slightly less negative than expected for a human population consuming $\mathrm{C} 3$ terrestrial foods, but the $\partial^{15} \mathrm{~N}$ value indicates a terrestrial rather than marine diet (Murray and Schoeninger, 1988; Mays, 1998). Thus, the lesser negative ratio of $\partial{ }^{13} \mathrm{C}$ may be caused by factors besides a marine diet, such as the consumption of $\mathrm{C} 4$ plants such as millet which was cultivated in some parts of eastern and southern Europe (Murray and Schoeninger, 1988; Schoeninger and Moore, 1992; Mays, 1998) as well as in the north-eastern region of the Iberian Peninsula (Alonso, 2000). 


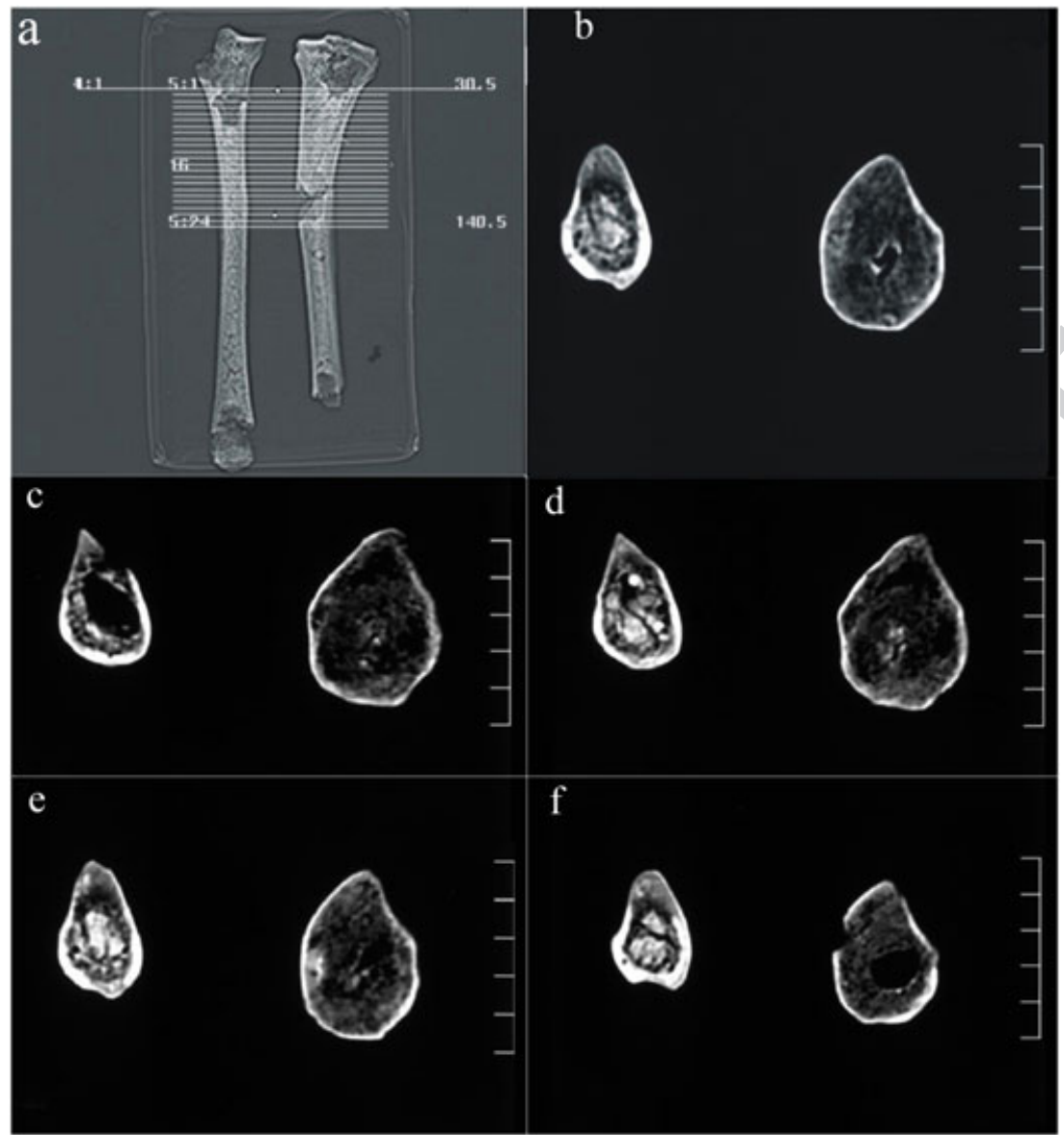

Figure 8. $_{\text {. }}$ Computed tomography image of both tibiae showing how the slices were made (a). They were made at the same time and in the same anatomical position. The images from $b$ to $f$ show some of the obtained slices as an example. In the right tibia, soil can be observed in the medullary cavity, but in the left the cortical bone is observed to be thinner than on the right, and there is a thickening of the cancellous bone which has reduced and in some cases obliterated the medullary cavity. These images correlate with figures $9_{\lambda}$ and $1 \theta_{\text {. }}$ This figure is available in colour online at wileyonlinelibrary.com/journal/oa.

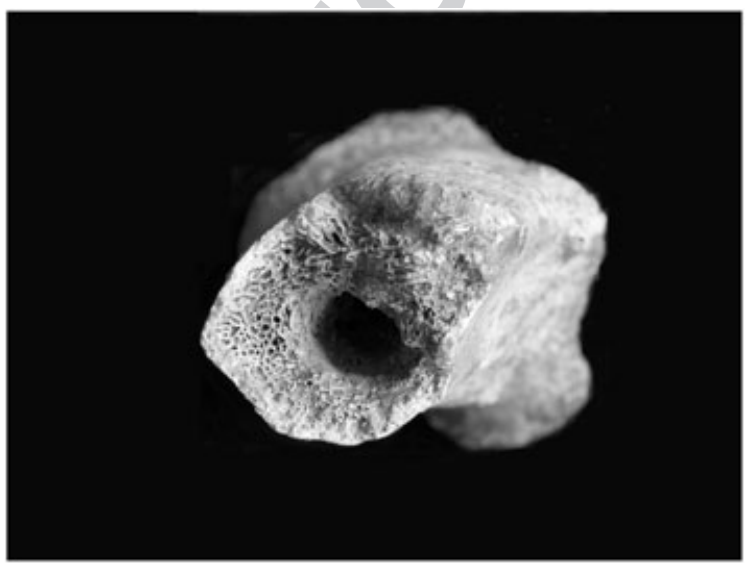

Figure 9. Post-depositional break in the midshaft of the left tibia showing the increase in cancellous bone and the reduction of the medullary cavirty.

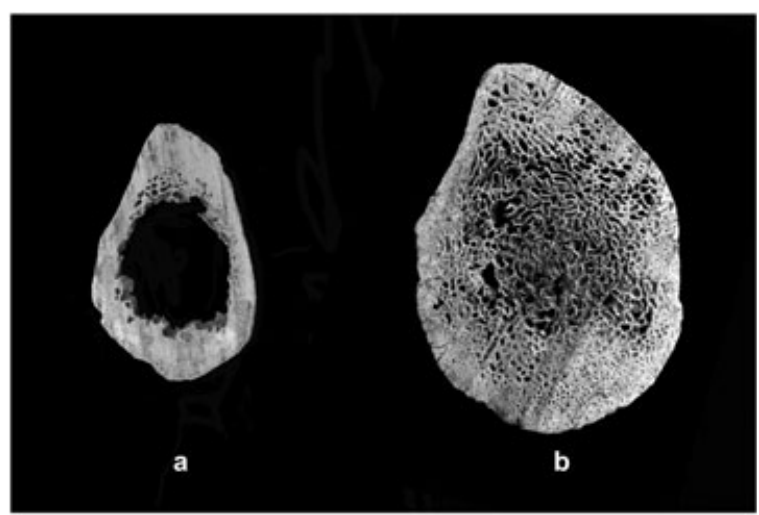

Figure 19 . Cross section obtained after sawing the right tibia (a) and the left tibia (b) though the mid proximal half of the shaft. This shows the increase of cancellous bone and obliteration of the medullary cavity in left tibia. 


\section{Differential diagnosis}

The observed skeletal changes indicate that the individual probably suffered from an infectious disease which caused chronic long-term inflammation. Only the left tibia is affected, while the rest of the preserved skeleton appears to be unaffected by pathological lesions that can be linked to the infection. Differential diagnoses of osteomyelitis, fungal infection, tuberculosis and treponematosis are considered as possible causes of the tibial lesions. However, other conditions should also be taken into account, such as monostotic fibrous dysplasia, Paget's disease, chronic varicose ulcers and traumatically induced non-specific infections.

Fibrous dysplasia is a benign process, characterized by the faulty differentiation of portions of the osteogenic mesenchyme where osteoblasts fail to undergo normal maturation (Feldman, 1995). It was first described by Lichtenstein in 1938. Later, Jaffe and Lichtenstein (1942) published on two different types of fibrous dysplasia: polyostotic and monostotic. The widespread skeletal involvement permits the exclusion of the polyostotic type in this study. Monostotic fibrous dysplasia most commonly affects the femoral neck as well as the tibiae and ribs principally in the second decade of the individual's life. The lesions arise centrally in the bone and are very rarely seen in the joints in adults, being normally located in the metaphysis or diaphysis. The bone lesions consist of islands of fibrous tissue that develop in the marrow space. From this location the fibrous lesions enlarge, often at the expense of cortical bone, which will be gradually replaced by fibrous tissue. Mineralization of this fibrous tissue takes place without the initial participation of osteoblasts, which are active in the mineralization of normal osteoid (Ortner, 2003). The weakened bony structure leads to mechanically induced deformities with or without major pathological fractures. In the proximal femur, this can result in the formation of a so-called 'shepherd's crook' deformity. There is also sometimes focal thinning of the overlying cortex, called 'scalloping from within'. Radiographically, fibrous dysplasia may appear as purely lytic lesions, and it is characterized by having a diffuse ground glass or hazy appearance due to the partial loss of the normal trabecular pattern in the cancellous bone (Park, 1993; Greenspan, 1996; Ortner, 2003). The absence of the characteristics described for monostotic fibrous dysphasia in the described skeleton allows us to disregard this disease.

Paget's disease is a chronic bone abnormality of unknown specific aetiology characterized by a profound increase in both new bone and resorption which results in a simultaneous mixture of lytic and sclerotic lesions, which can cause enlargement of the bones; the tibia generally adopts a sabre-shaped morphology. It may affect a single bone, several or many bones, but never the entire skeleton (Resnick and Niwayama, 1988; Ortner, 2003). Paget's disease occurs more commonly in the older age groups ( $>40$ years), in males, and in populations of European descent, but it is rare in Africans and Asians. The disease is not rare in a limited form, but severe multiosseous involvement is uncommon. The lesions show the following distribution: sacrum, $57 \%$; spine $50 \%$; femora, $46 \%$; skull, $39 \%$; sternum, $32 \%$; pelvis, $30 \%$; clavicle, $18 \%$; tibia, $11 \%$; ribs, $10 \%$ and humerus, 6\% (Ortner, 2003). These data indicate the great predilection for the axial skeleton, which often is the only area involved. The femur and tibia are the most common sites of involvement in the major long bones, and the asymmetric distribution, thickened trabeculae and cortices, and enlargement of the involved bone are all typical of Paget's disease (Ortner, 2003).

The cancellous bone at either ends of long bones is usually the initial area for the lytic process which then progresses towards the apposing ends with a V-shaped leading edge, leaving dense bone in the sclerotic phase. The cortex becomes thickened though the medullary cavity is retained. New bone is deposited causing antero-lateral bowing of the femur and medio-lateral bowing of the tibia. Bowing, especially in the weightbearing bones, occurs mainly as an expression of the mechanical inferiority of the abnormal bone formed. Fissure-like stress fractures (infractions) are common, and the newly-formed bone is lamellar in character; it does not remodel in response to stress and therefore does not have the strength of normal bone. Diagnosis of Paget's disease is made on typical radiological characteristics: a fibrous bony structure, the presence of a ' $\mathrm{V}$ ' shape of demineralization and focal radiodensity of the epiphyses (Resnick and Niwayama, 1988; Claired and Dagorn, 1994; Mirra et al., 1995a, 1995b; Aufderheide and Rodríguez-Martín, 1998; Ortner, 2003). The absence of these characteristics in this skeleton allows us to disregard Paget's disease as the condition affecting the tibia.

In very advanced cases, chronic varicose veins leading to soft tissue ulcers can leave very specific bone changes on the lower leg bones. Vascular impressions in the periosteal new bone formed are usually apparent. These impressions are spiculated, sharp edged and sometimes have a pronounced mosaic shape (Resnick and Niwayama, 1988; Pinheiro et al., 2004). The absence of these characteristics here allows this condition to be discarded.

As for specific infectious diseases, pyogenic osteomyelitis could be a possible cause of the lesions observed. We 
should distinguish between (i) acute osteomyelitis, where lysis is dominant or (ii) chronic osteomyelitis, where the formation of an involucrum, sequestrum and cloacae predominate. However, none of these characteristics can be observed in the individual here. With regard to secondary osteomyelitis, caused by an infection, trauma or other condition, the observed lesions could be a consequence of the penetration of microorganisms from the exterior through a wound or from an open fracture. If this were the case here, there would be an inflammatory reaction and the production of new well-remodelled bone distributed irregularly and with a spiculated appearance. There may or may not be lacunae evident or evidence of cloacae with eventual sclerotic areas (Steinbock, 1976; Campillo, 2001). The absence of these characteristics allows this condition to be discarded.

At this point, sclerosing osteomyelitis of Garré should also be considered. This disease is confined normally to a single bone, but multiple areas of the bone can be involved. Infants and children are affected more commonly. The usual location is the tibia followed by the femur. No pus is formed, and no acute phase occurs. The predominant feature of this chronic condition is sclerotic and fusiform thickening of the cortex of the affected bone (Resnick and Niwayama, 1988; Aufderheide and Rodríguez-Martín, 1998). These characteristics are contrary to those observed here, where there is encroachment into the medullary cavity of coarse cancellous bone tissue and cancellization of the cortex. For this reason, this condition is dismissed.

The possibility of a fungal infection, such us sporotrichosis and cryptococcosis, which may have been present in Europe in the Roman period, has also been considered. However, lesions of fungal infections are lytic and not compatible with the lesions observed in the studied skeleton. Furthermore, the lesions of sporotrichosis appear mainly on the hands and feet (Aufderheide and Rodríguez-Martín, 1998; Ortner, 2003).

With regard to tuberculosis, although bone changes are seen on the skeleton, they are rarely characterized by osteitis affecting the diaphysis of a long bone. Skeletal alteration, usually in the spine, is produced by the dissemination of the bacteria haematogenously or lymphatically, and the cancellous bone is affected rather than the cortex and medullary cavity. The process in the long bones tends to remain localized mostly to the metaphyseal and epiphyseal areas. In the rare case where the diaphysis is affected, lesions on more than one bone, along with alteration to the articular surfaces, are observed. The joints can also become involved through metaphyseal abscesses that spread to the joint surfaces; this may develop into septic arthritis and even ankylosis. The general pattern of involvement in bone and joint tuberculosis is characterized by lysis and very little or any bone formation (Roberts and Buikstra, 2003). Often, the involved bone also can show perifocal or general osteoporosis (Aufderheide and Rodríguez-Martín, 1998; Ortner, 2003). Therefore, this disease can also be disregarded.

The treponematoses, in their widest sense, are infections that produce lesions such as those described in the skeleton here studied. For example, in the cranium, venereal syphilis can produce the characteristic diagnostic chronic lesions of caries sicca on the vault (central destruction surrounded by reactive bone formation that creates the crater-like lesion). Unfortunately, the neurocranium of the St Nicasi's individual was not recovered. In the post-cranial skeleton, the sabre shape of the tibia, along with thickening of the bone caused by osteoperiostitis, the small raised plaques of new bone bridging over minor blood vessels, the invasion of the medullary cavity by trabecular bone and cancellization of the cortical bone, producing its reduction in thickness, are typical characteristics of treponematosis (Ortner, 2003). These changes, along with the absence of cloacae, are typical of nongummatous lesions of treponemal disease (Hackett, 1976; Steinbock, 1976; Claired and Dagorn, 1994; Aufderheide and Rodríguez-Martín, 1998; Ortner, 2003).

The lesions produced by yaws, venereal syphilis and endemic syphilis are similar. However, the causal agent of yaws, Treponema pallidum sub-species pertenue, is adapted to humid tropical environments today, and it is very unlikely that it was present in Western Europe in the past. Consistent with this, there is no historical evidence of this infection in the Iberian Peninsula. However, a migrant origin of the individual from a tropical area could be argued, but the obtained $\partial^{13} \mathrm{C}$ value of -18.66 from stable isotope analysis (see above) is low enough to disregard such a tropical origin. Individuals from tropical regions have low $\partial{ }^{13} \mathrm{C}$ values ( -9 to -4$)$ due to the great consumption of C4 plants, and animals which eat C4 plants (Mays, 1998). Therefore, it would seem reasonable to eliminate a diagnosis of yaws in the skeleton presented here.

Venereal syphilis is caused by Treponema pallidum sub-species pallidum and, depending on how it is contracted, it is either congenital or acquired. Venereal syphilis is found all over the world today, regardless of climate; the differences in distribution are mainly related to socio-cultural factors (Benenson, 1984), and it is more frequent in urban than in rural areas (Aufderheide and Rodríguez-Martín, 1998). Congenital syphilis is transmitted by haematogenous dissemination of the spirochetes from the placenta to the fetus; the rate of 
congenital syphilis is about of $80 \%$ in the offspring of infected mothers. Mortality is extraordinarily high, causing frequent miscarriages and premature death in children, and those who survive usually present serious and persistent health problems. For example, spirochetes can affect the development of the teeth (Hutchinson's incisors, Mulberry molars - see Hillson et al., 1998) and inhibit normal development of bones (Aufderheide and Rodríguez-Martín, 1998). Therefore, a diagnosis of congenital syphilis in this skeleton is very unlikely because, apart from not showing the typical morphological characteristics, the skeleton is that of an adult about 30 years old, and it is unlikely that he would have survived for so long in the Roman period. Acquired venereal syphilis is transmitted through sexual intercourse with an infected person, although indirect transmission is possible through infected objects or the non-sexual contact of exudates from open lesions (Aufderheide and Rodríguez-Martín, 1998). Venereal syphilis mainly affects individuals between 15 and 30 years of age, and it is two or three times more frequent in males than in females (Aufderheide and Rodríguez-Martín, 1998). According to these epidemiological data, the observations in the skeleton under study here are consistent with acquired venereal syphilis.

With regard to endemic syphilis or bejel, there is documented evidence that it was common before the medieval period (Willcox, 1972). It is localized in populations where hygiene is poor and the climate is warm and dry. It is transmitted by contact with infected objects such as drinking vessels, and it is currently seen in populations of the developed world (Mehues, 1996). The characteristics of the causal microorganism (Treponema pallidum sub-species endemicum) are very similar to venereal syphilis to the extent that laboratory tests are very similar. However, endemic syphilis is generally contracted in childhood (Willcox, 1972) and can affect skeletal growth. In endemic syphilis and yaws, the latter of which is also contracted in childhood, affected tibiae have an accelerated growth rate and, because they are 'fixed' in two places to the fibula, they develop anterior bowing (Steinbock, 1976). Venereal syphilis presents 'pseudobowing' due to the bone deposition on the anterior tibial crest (Jaffe, 1972; Steinbock, 1976). In endemic syphilis, both tibiae are affected, while in venereal syphilis, the involvement can be unilateral or bilateral (Wallace, 1919; Willard-Roberts, 1920; Thomason and Mayoral, 1940; Resnick and Niwayama, 1988; Hershkowitz et al., 1994; Rothschild and Rothschild, 1995; Rothschild et al., 2000). Furthermore, in venereal syphilis, when the tibia suffers severe remodeling causing its sabreshaped morphology, the observed periosteal reaction is much less important than the remodelling. At times, the periosteal lesions are negligible such that the changes are not visible to the naked eye. However, in endemic syphilis, when there is severe remodelling, it is always related to extensive periosteal reaction which makes the pathological lesions evident (Thomason and Mayoral, 1940; Zink et al., 1994; Rothschild and Rothschild, 1995; Molto, 2005).

Therefore, we conclude that the pathological bone changes outlined in this skeleton seem to represent treponemal disease, and, although we are inclined to a diagnosis of venereal syphilis, it is not possible to determine with any great certainty that the evidence illustrates treponematosis, and even less venereal syphilis. It is difficult to be certain because the individual has only one bone affected, the tibia, although Hackett (1976) and Ostendorf-Smith (2006) argue that the shaft expansion of the tibia (fusiform and/or thickening), the presence of periosteal plaques and sclerosing periostitis in a tibia displaying a saber-shaped morphology are indicative of treponematosis; the tibia is also the most common site of skeletal involvement in the treponematoses (Powell, 1988), but, until now, it has been the lesions of caries sicca on the cranial vault that have been considered as diagnostic of venereal syphilis. For this reason, a diagnosis of treponematosis must remain as a tentative suggestion.

\section{Discussion}

Although the cranium is considered to be the most important area of the skeleton for observing lesions that are diagnostic of venereal syphilis, the tibia is much more frequently affected than the cranium. Specifically, in bejel, the tibia is affected in $61 \%$ of cases compared to only $4 \%$ in the cranium. In venereal syphilis, the tibia is affected in $36 \%$ of cases, and the cranium only in $14 \%$ (Ortner, 2003). Perhaps, the reason that not more skeletons with treponematosis have been diagnosed in the Old World is because of many of them have only affected tibiae, and there is a reluctance to diagnose venereal syphilis without observing the cranium. We are aware that diagnosing treponematosis using the tibia is not a straightforward matter but that the difficulty mainly resides, as pointed out by Roberts (1994), in the lack of experience in identifying such pathological lesions, for many, until recently. Due to the importance of the tibia in this condition, this bone should be taken into account, along with the methods described for its diagnosis (Rothschild and Rothschild, 1994, Q2 Molto, 2005). 
The observed lesions of the tibia in the skeleton from Gavà, characterized by encroachment into the medullary cavity of coarse cancellous bone, cancellization of the cortex, thickening of the diaphysis, the presence of small raised plaques of new bone bridging over minor blood vessels, a sabre-shaped morphology and a predominance of bone remodeling rather than periosteal reaction, are the typical characteristics of tibiae affected by treponematosis (Hackett, 1976). For this reason, we believe that this skeleton represents a possible example of treponematosis. Radiocarbon dating indicates that the skeleton is firmly from a pre-Columbian date, between the $2^{\text {nd }}$ and $3^{\text {rd }}$ centuries $A D$. This Roman male could add to a very small body of paleopathological data which indicates that treponemal disease was present in Europe prior to Columbus' voyages, specifically in the north-east of the Iberian Peninsula.

In spite of the debate, based on paleopathological evidence, it seems clear that treponematosis existed in both New (Baker and Armelagos, 1988; Dutour et al., 1994, Powell and Cook, 2005) and Old Worlds before Columbus' voyages (Dutour et al., 1994). There is evidence that in the Old World, it existed before 1493 in Europe, Iraq, the Pacific Islands and India (Brothwell, 1968, 2006; Baker and Armelagos, 1988), the oldest evidence dating back to the Iron Age and the Chalcolithic period in India (Lukacs et al., 1986; Rao et al., 1996). In Europe, evidence dates to the Mediaeval and post-Mediaeval periods, from the $12^{\text {th }}$ century onwards (Roberts, 1994; Stirland, 1994; Malgosa et al., 1996; Mays et al., 2003; Solórzano et al., 2004; Erdal, 2006), except for those skeletons excavated in France (Pálfi et al., 1992; Blondiaux and Alducle-Bagouse, 1994), Italy (Henneberg and Henneberg, 1994) and England (Simmonds et al., 2008) which are dated earlier than the $4^{\text {th }}$ century $\mathrm{AD}$ and displayed lesions indicative of congenital syphilis. The present study suggest that treponematosis was possibly present in the $2^{\text {nd }}$ century $A D$ in the Iberian Peninsula, suggesting that it is a much older disease than has been previously believed, according to paleopathological data.

This study could be very relevant to contact made between Spain and the Americas in the $15^{\text {th }}$ century AD. The presence of the St Nicasi's individual in the Iberian Peninsula would suggest that treponematosis had arrived in the Iberian Peninsula and Western Europe at least during the Roman expansion from Italy, well before Columbus' voyages and before the Crusades in the Middle Ages, contrary to some authors' suggestions (Mays et al., 2003). This hypothesis becomes stronger when skeletons with probable congenital syphilis from Italy (Henneberg and Henneberg, 1994), France (Pálfi et al., 1992; Blondiaux and Alduc-le-Bagouse, 1994) and
England (Simmonds et al., 2008), also dating to the late Roman Imperial period, are taken into account. If treponematosis had arrived in the Iberian Peninsula during or before the Roman expansion, it invalidates the Columbian hypothesis and points to a greater antiquity of the disease.

\section{Conclusion}

The skeleton analyzed here potentially provides further evidence of pre-Columbian treponematosis in Europe, specifically in the north-east of the Iberian Peninsula. Radiocarbon dating provides a Roman date for the remains. This skeleton could be important for its contribution to the history of treponemal disease, along with those found previously in England, France and Italy, indicating that treponematosis existed in western Europe before the Crusades or the arrival of the Spanish in America. These studies could illustrate that treponematosis in Europe did not occur recently in human history ( 500 years ago) from a New World progenitor related to yaws, supporting the molecular data obtained by Gray et al. (2006), who found great variability in the genetic sequences of Treponema pallidum subspecies pallidum whose origin is inferred to be within the past 500 years. In fact, if treponematosis has existed in India since the Iron Age, it is easier to think that the origin of the treponematoses in Europe may have been in the eastern area of the Old World, as suggested by Mays (2003), and not the New World.

\section{Acknowledgements}

This study has been sponsored by ArqueoCat SL. The authors thank Mr. Enrique Jorcano and Mr. Ernesto Espinoso from the Radiology Department of the Hospital Clinic of Barcelona for their help doing the CT scans. The authors would also like to thank Professor Milton Nuñez from the University of Oulo, Professor Daniel Turbón from the University of Barcelona and Dr Nicholas Marquez-Grant from LGC Forensic for their valuable commentaries.

\section{References}

Alemán I, Botella MC, Ruiz L. 1997. Determinación del sexo en el esqueleto postcraneal. Estudio de una población mediterránea actual. Archivo Español de Morfolgía 2: 7-17.

Alonso N. 2000. Registro arqueobotánico de Cataluña occidental durante el II y I milenio a.n.e. Complutum 1 1: 221-238. 
Arneborg J, Heinemeier J, Lynnerup N, Nielsen HL, Rud N, Sveinbjörnsdóttir AE. 1999. Change of diet of the Greenland Vikings determined from stable carbon isotope analysis and ${ }^{14} \mathrm{C}$ dating of their bones. Radiocarbon 42: 157-168.

Arrizabalaga J. 1993. Syphilis. In The Cambridge world bistory of buman disease, KF Klipe (ed.). Cambridge University Press: Cambridge; 1025-1033.

Aufderheide AC, Rodríguez-Martín C. 1998. The Cambridge encyclopedia of buman paleopathology. Cambridge University Press: Cambridge.

Baker BJ, Armelagos GJ. 1988. The origin and the antiquity of syphilis: paleopathological diagnosis and interpretation. Current Antbropology 29: 703-737.

Benenson AS. 1984. El control de las enfermedades transmisibles en el hombre (Control of transmissible disease in man), 13th ed. Organización Panamericana de la Salud: Washington, DC.

Beukens RP, Gurfinkel DM, Lee HW. 1986. Progress at the iso-trace radiocarbone Laboratory. Radiocarbon 28: 229-236.

Blondiaux J, Alduc-le-Bagouse A. 1994. Une tréponématose du Bas-Empire romain en Normandie? In L'origine de la syphilis en Europe, avant ou après 1493? O Dutour, G Palfi, J Berato, JP Brun (eds.). Editions Errance/Centre Archeologique du Var: Toulon; 99-100.

Bouwman AS, Brown TA. 2005. The limits of biomolecular palaeopathology: ancient DNA cannot be used to study venreal syphilis. Journal of Archaeological Science 32: 703-713.

Brooks S, Suchey JM. 1990. Skeletal age determination based on the os pubis: a comparison of the AscadiNemeskeri and Suchey-Brooks methods. Human Evolution 5: 227-238.

Brothwell DR. 1968. Skeletal biology of earlier buman populations. Pergamon Press: London.

Brothwell DR. 1987. Desenterrando buesos. Fondo de cultura económica: México.

Brothwell DR. 2006. North America treponematosis against the bigger world picture. In The myth of the syphilis. The Natural History of treponematosis in North America, ML Powell, DC Cook (eds.). University press of Florida: Florida; 480-496.

Campillo C. 2001. Introducción a la paleopatología. edicions Bellaterra: Bercelona.

Claired D, Dagorn J. 1994. Manifestations osseuses de la syphilis: étude radiographique et diagnostic differential. In L'origine de la sypbilis en Europe, avant ou après 1493? O Dutour, G Palfi, J Berato, JP Brun (eds.). Editions Errance/Centre Archeologique du Var: Toulon; 32-35.

Cockburn TA. 1961. The origin of the treponematoses. Bulletin of the World Health Organization 24: 221-228.

Crosby AW. 1969. The early history of syphilis: a reappraisal. American Antbropologist 71: 218-227.

Dawes JD, Magilton JR. 1980. The cemetery of St. Helen-onthe-Walls, Aldwark. Archaeology of York 12/1. Council for British Archaeology: York.

Dennie CC. 1962. A bistory of sypbilis. Charles C Thomas: Springfield.

Dutour O, Pálfi G, Berato J, Brun JP (eds.). 1994. L'oridine de la sypbilis en Europe, avant ou après 1493? Editions Errance/ Centre Archeologique du Var: Toulon.
Erdal YS. 2006. A pre-Columbian case of congenital syphilis form Anatolia (Nicaea, 13th Century AD). International Journal of Osteoarchaeology 16: 16-33.

Feldman F. 1995. Tuberous sclerosis, neurofibromatosis, and fibrous dysplasia. In D Resnik (ed.). Diagnosis of bone and joint disorders, 3rd ed. Saunders: Philadelphia, 4353-4395.

Ferembach D, Schwidetzky I, Stloukal M. 1980. Recommendations for age and sex diagnoses of skeleton. Journal of Human Evolution 9: 517-549.

Goff CW. 1967. Syphilis. In Diseases in Antiquity: A survey of the Diseases, injuries and surgery of early populations, D Brothwell, AT Sandison (eds.). Charles C. Thomas: Springfieldi 279-294.

Gray RR, Mulligan CJ, Molini BJ, Sun ES, Giacani L, Gordones C, Kitchen A, Lukehart SA, Centurion-Lara A. 2006. Molecular evolution of the tprC, D, I, K, G and J genes in the pathogenic genus Treponema. Molecular Biology and Evolution 23: 2220-2233.

Greenspan A. 1996. Orthopedic Radiology, 2nd ed. LippincottRaven: Philadelphia.

Hackett CJ. 1963. On the origin of the human treponematoses. Bulletin of the World Health Organization 29: 7-41.

Hackett CJ. 1967. The human treponematoses. In Diseases in antiquity, D Brothwell, A Sandison (eds.). Charles C. Thomas: Springfield, $152-169$.

Hackett CJ. 1976. Diagnostic criteria of sypbilis, yaws and treponarid (treponematoses) and of some other diseases in dry bones. Springer: Berlin.

Harper KN, Ocampo PS, Steiner BM, George RW, Silverman MS. 2007. On the Origin of the Treponematoses: A Phylogenetic Approach. PLoS Neglected Tropical Diseases 2(1): e148. DOI: 10.1371/journal.pntd.0000148.

Harrison LW. 1959. The origin of syphilis. The British Journal of Venereal Diseases 35: 1-7.

Henneberg M, Henneberg RJ. 1994. Treponematosis in ancient Greeck colony of Metaponto, Southern Italy, 580-250 BCE. In L'origine de la sypbilis en Europe, avant ou après 1493? O Dutour, G Palfi, J Berato, JP Brun (eds.). Editions Errance/ Centre Archeologique du Var: Toulon; 92-98.

Hershkowitz I, Rothschild BM, Wish-Baratz S, Rothschild C. 1994. Natural variation and differential diagnosis of skeletal changes in Bejel. In O Dutour, G Palfi, J Berato, JP Brun (eds.). L'origine de la sypbilis en Europe, avant ou après 1493? Editions Errance/Centre Archeologique du Var: Toulon; 81-87.

Hillson S, Grigson C, Bond S. 1998. Dental defects of congenital syphilis. American Journal of Physical Antbropology 107: 25-40.

Holcomb RC. 1930. Who gave the world syphilis? The Haitian myth. Froben Press: New York.

Holcomb RC. 1934. Christopher Columbus and the American origin of syphilis. US Naval Medical Bulletin 34: 401-430.

Holcomb RC. 1935. The antiquity of syphilis. Medical Life 42: 275-325.

Hudson EH. 1958. The treponematoses- or treponematosis? The British Journal of Venereal Diseases 34: 22-23. 
Hudson EH. 1963. On the origin of the human treponematoses. Bulletin of the World Health Organization 29: 7-41.

Hudson EH. 1965. Treponematosis and man's social evolution. American Antbropologist 67: 885-901.

Hudson EH. 1968. Christopher Columbus and the history of syphilis. Acta Tropica (Basel) 25: 1-16.

Jaffe H. 1972. Metabolic, degenerative, and inflamatori disease of bones and joints. Lea and Febiger: Philadelphia.

Jaffe H, Lichtenstein L. 1942 Fibrous dysplasia of bone. A condition affecting one, several or many bones, the graver cases of which may present with abnormal pigmentation of skin, premature sexual development, hyperthyroidism or still other extraskeletal abnormalities. Archives of Pathology, Chicago 33: 777-816.

Kampmeier RH. 1984. Early development of knowledge of sexually transmitted diseases. In Sexually transmitted diseases, KK Holmes, PA Mardh, PF Sparling, PJ Weisner (eds.). McGraw-Hill: New York; 19-29.

Lichtenstein L. 1938. Polyostotic dysplasia. Archives of Surgery 36: 874-898.

Lovejoy CO, Meindl RS, Mensforth RP, Barton TJ. 1985. Multifactorial age determination of skeletal age at death: a method and blind tests of its accuracy. American Journal of Pbysical Antbropology 68: 1-14.

Lukacs JR, Bogorad R, Walimbe SR, Dunbar DC. 1986. Paleopathology at Inamgaon: a post-Harappan agrarian village in Western India. Proceedings of the American Pbilosopbical Society 130: 289-331.

Malgosa A, Aluja MP, Isidro A. 1996. Pathological evidence in newborn children from the sixteenth century in Huelva (Spain). International Journal of Osteoarchaeology 6: 388-396.

Mays S. 1998. The archaeology of buman bones. Routledge/English Heritage: London.

Mays S, Crane-Kramer G, Bayliss A. 2003. Two probable cases of treponemal disease of Medieval date from England. American Journal of Physical Antbropology 120: 133-143.

Mehues A. 1996. Non-venereal treponematoses. Medicine (Baltimore) 24: 69-71.

Mirra JM, Brien EW, Tehranzadeh J. 1995a. Paget's disease of bone: review with emphasis on radiologic features, part I. Skeletal Radiology 24: 163-171.

Mirra JM, Brien EW, Tehranzadeh J. 1995b. Paget's disease of bone: review with emphasis on radiologic features, part II. Skeletal Radiology 24: 173-184.

Molto JE. 2005. Endemic treponematosis in pre- and post contact Pericue of the Cape Region of Baja California Sur. In The myth of syphilis, ML Powell, DC Cook (eds.). University Press of Florida: Gainesville; 350-367.

Mook WG, Streurman HJ. 1983. Physical and chemical aspects or radiocarbon dating. In Proceedings of the First International Symposium: ${ }^{14} \mathrm{C}$ and Archaeology, Groningen 1981, WG Mook, HT Waterbolk (eds.). PACT: Strasbourg; 31-55.

Mulligan CJ, Norris SJ, Lukehart SA. 2008. Molecular Studies in Treponema pallidum Evolution: Toward Clarity? PLoS Neglected Tropical Diseases 2(1): e184 DOI: 10.1371/ journal.pntd.0000184.
Murray M, Schoeninger M. 1988. Diet, status, and complex social structure in Iron Age Central Europe: Some contributions of bone chemistry. In Tribe and Polity in Late Prebistoric Europe, D Gibson, M Geselowitz (eds.). Plenum Press: London; 155-176.

Ortner DJ. 2003. Identification of pathological conditions in buman skeletal remains. Academic Press: San Diego.

Ostendorf-Smith M. 2006. Treponemal disease in the Middle Archaic to Early Woodland periods of the Western Tennessee River Valley. American Journal of Pbysical Antbropology 131 : 205-217.

Pálfi G, Dutour O, Borreani M, Brun JP, Berato J. 1992. PreColumbian congenital syphilis from the late antiquity in France. International Journal of Osteoarchaeology 2: 245-261.

Park YK. 1993. Osteofibrous Dysplasia: a clinicopathologic study of 80 cases. Human Pathology 24: 1339-1347.

Pinheiro J, Cunha E, Cordeiro C, Veira DN. 2004. Bridging the gap between Forensic Anthropology and Osteoarchaeology A case of vascular pathology. International Journal of Osteoarchaeology 1: 137-144.

Powell ML. 1988. Status and bealt in Prebistory. Smithsonian Institution Press: Washington, DC.

Powell ML, Cook DC (eds.). 2005. The myth of the sypbilis. The Natural History of treponematosis in North America. University Press of Florida: Florida.

Prida-Trujillo D. 2007. C/ Sant Nicasi, 18-24 Gavà,(Baix Llobregat). Novembre - Desembre 2005. Memòria de la intervenció arqueològica preventiva. Generalitat de Catalunya: Barcelona.

Rao VV, Vasulu TS, Rector Babu ADW. 1996. Possible paleopathological evidence of treponematosis from a megalithic site at Agripalle, India. American Journal of Pbysical Antbropology 100: 49-55.

Resnick D, Niwayama G. 1988. Diagnosis of bone and joint disorders, 2nd ed. W B Saunders Company: Toronto.

Richards MP, Hedges REM. 1999. Stable isotope evidence for similarities in the types of marine foods used by late Mesolithic humans at site along the Atlantic coast of Europe. Journal of Archaeological Science 26: 717-722.

Rissech C, Malgosa A. 1991. Importancia relativa de la longitud del pubis y la anchura del ilion en el estudio del dimorfismo sexual de los coxales. Boletín de la Sociedad Española de Antropología Biológica 12: 29-43.

Rissech C, Malgosa A. 1997. Sex prediction by discriminant function with central portion measures of innominate bones. Homo 48: 22-32.

Rissech C, Estabrook GF, Cunha E, Malgosa A. 2006. Using the acetabulum to estimate age at death in adult males. Journal of Forensic Science 51: 213-229.

Rissech C, Estabrook GF, Cunha E, Malgosa A. 2007. Estimation of age-at-death for adult males using the acetabulum, applied to four Western European populations. Journal of Forensic Science 54: 774-779.

Roberts C. 1994. Treponematosis in Gloucester, England: a theoretical and practical approach to the pre-Columbian theory. In L'origine de la sypbilis en Europe, avant ou après 1493? O Dutour, G Pálfi, J Berato, JP Brun (eds.). Editions Errance/Centre Archeologique du Var: Toulon; 102-108. 
Roberts CA. 2006 A view from afar: bioarchaeology in Britain. In Bioarchaeology. Contextual analysis of buman remains, J Buikstra, L Beck (eds.). Elsevier: New York; 417-439.

Roberts CA, Buikstra JE. 2003. The bioarchaeoogy of tuberculosis. A global view on a reemerging disease. University Press of Florida: Gainesville, Florida.

Rothschild B, Rothschild C. 1995. Treponemal diseases revised: skeletal discriminators for yaws, bejel, and venereal syphilis. Clinical Infectious Diseases 20: 1402-1408.

Rothschild BM, Luna F, Coppa A, Rothschild C. 2000. First European exposure to syphilis: the Dominican Republic at the time of Columbian contact. Clinical Infectious Disease 31: 936-941.

Safont S, Malgosa A, Subirà E. 2000. Sex assessment on the basis of long bone circumference. American Journal of Physical Antbropology 113: 317-328.

Schoeninger M, Moore K. 1992. Bone stable isotope studies in archaeology. Journal of World Prebistory 6: 247-296.

Simmonds A, Márquez-Grant N, Loe L. 2008. Life and death in a Roman city. Oxford Archaeology Monographs 6: 48.

Solórzano E, Díaz N, Montiel R, Cañadas MP, Isidro A, Malgosa A. 2004. Análisis molecular de casos de treponematosis congénita en individuos neonatales del siglo XVI (Huelva-España). In Biologia de poblaciones bumanas: Diversidad tiempo y espacio, JE Egocheaga (ed.). Edita Sociedad Española de Antropología Física: Oviedo; 247-253.

Steinbock RT. 1976. Paleopatbological diagnosis and interpretation. Charles C. Thomas: Springfield.

Stirland A. 1994. Evidence for pre-Columbian treponematosis in Medieval Europe. In L'origine de la sypbilis en Europe, avant ou après 1493? O Dutour, G Pálfi, J Berato, JP Brun (eds.). Editions Errance/Centre Archeologique du Var: Toulon; 109-115.
Stuiver M, Polach HA. 1977. Reporting of ${ }^{14} \mathrm{C}$ data. Radiocarbon 19: 355-363

Stuiver M, Reimer PJ. 1986. A computer program for radiocarbon age calculation. Radiocarbon 28: 1022-1030.

Stuiver M, Reimer PJ. 1993. Extended ${ }^{14} \mathrm{C}$ data base and revised CALIB $3.0{ }^{14} \mathrm{C}$ age calibration program. Radiocarbon 35: 215-230.

Stuiver M, Reimer P, Bard E, Beck J, Burr G, Hughen J, Kromer B, McCormac G, Van der Pilcht J, Spurk M. 1998. Intcal 98 radiocarbon age calibration. 24,000-0 cal. BP. Radiocarbon 40: 1041-1083.

Thomason HA, Mayoral A. 1940. Syphilitic osteomyelitis. Journal of Bone and Joint Surgery (American volume) 22: 203-206.

Von Hunnius TE, Yang D, Eng B, Waye JS, Saunders SR. 2007. Digging deeper into the limits of ancient DNA research on syphilis. Journal of Archaeological Science 34: 2091-2100.

Wallace JO. 1919. Diagnosis of syphilis of bones and joints. Journal of Bone and Joint Surgery (American volume) 1: 258-293.

Willard-Roberts P. 1920. Syphilitic and tuberculous joints. Journal of Bone and Joint Surgery (American volume) 2: 265-267.

Willcox RR. 1972. Treponemal evolution. Transactions of the St. Jobn's Hospital Dermatological Society 58: 21-37.

Williams HU, Rice JP, Lacayo JR. 1927. The American origin of syphilis. Archives of Dermatology Syphilol 16: 683-696.

Zink A, Parsche F, Nerlich A, Wiest I. 1994. Probable case of treponematosis in Munich collection of Peruvian skeletons. In L'origine de la sypbilis en Europe, avant ou après 1493? O Dutour, G Pálfi, J Berato, JP Brun (eds.). Editions Errance/Centre Archeologique du Var: Toulon, 202-204. 


\section{Author Query Form}

\section{Journal: International Journal of Osteoarchaeology}

\section{Article: oa_1293}

Dear Author,

During the copyediting of your paper, the following queries arose. Please respond to these by annotating your proofs with the necessary changes/additions.

- If you intend to annotate your proof electronically, please refer to the E-annotation guidelines.

- If you intend to annotate your proof by means of hard-copy mark-up, please refer to the proof mark-up symbols guidelines. If manually writing corrections on your proof and returning it by fax, do not write too close to the edge of the paper. Please remember that illegible mark-ups may delay publication.

Whether you opt for hard-copy or electronic annotation of your proofs, we recommend that you provide additional clarification of answers to queries by entering your answers on the query sheet, in addition to the text mark-up.

\begin{tabular}{|c|l|c|}
\hline Query No. & \multicolumn{1}{|c|}{ Query } & Remark \\
\hline Q1 & $\begin{array}{l}\text { AUTHOR: Figure 3 was not sequentially cited in the text, it was inserted here. Please } \\
\text { check. }\end{array}$ & $\begin{array}{l}\text { AUTHOR: "Rothschild and Rothschild, 1994" is cited in text but not given in the } \\
\text { reference list. Please provide details in the list or delete the citation from the text. }\end{array}$ \\
\hline Q2 & \\
\hline
\end{tabular}


Required software to e-Annotate PDFs: Adobe Acrobat Professional or Adobe Reader (version 8.0 or above). (Note that this document uses screenshots from Adobe Reader $\mathrm{X}$ )

The latest version of Acrobat Reader can be downloaded for free at: http://get.adobe.com/reader/

Once you have Acrobat Reader open on your computer, click on the Comment tab at the right of the toolbar:

닙

This will open up a panel down the right side of the document. The majority of tools you will use for annotating your proof will be in the Annotations section, pictured opposite. We've picked out some of these tools below:

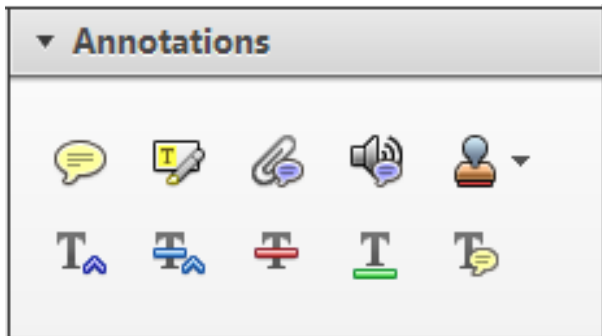

1. Replace (Ins) Tool - for replacing text.

Strikes a line through text and opens up a text box where replacement text can be entered.

\section{How to use it}

- Highlight a word or sentence.

- Click on the Replace (Ins) icon in the Annotations section.

- Type the replacement text into the blue box that appears.

Idard tramework for the analysis of $\mathrm{m}$ icy-Nevertheless, it also led to exog،

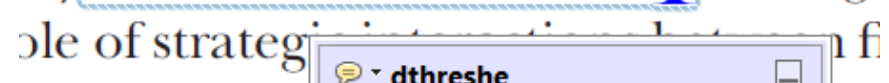
aber of comp 08/06/2011 15:58:17

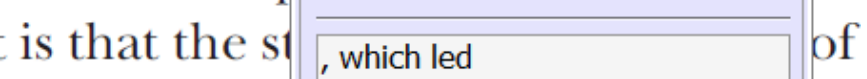
nain compo: be level, are exc nc

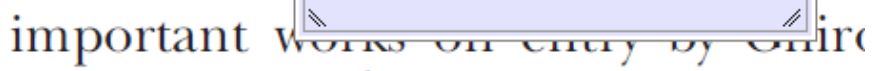
M heneferth) ${ }^{1}$ we anen the 'hlark $\mathrm{h}$

3. Add note to text Tool - for highlighting a section to be changed to bold or italic.

T Highlights text in yellow and opens up a text box where comments can be entered.

\section{How to use it}

- Highlight the relevant section of text.

- Click on the Add note to text icon in the Annotations section.

- Type instruction on what should be changed regarding the text into the yellow box that annears.

namic responses of mark ups ent with the VAR evidence

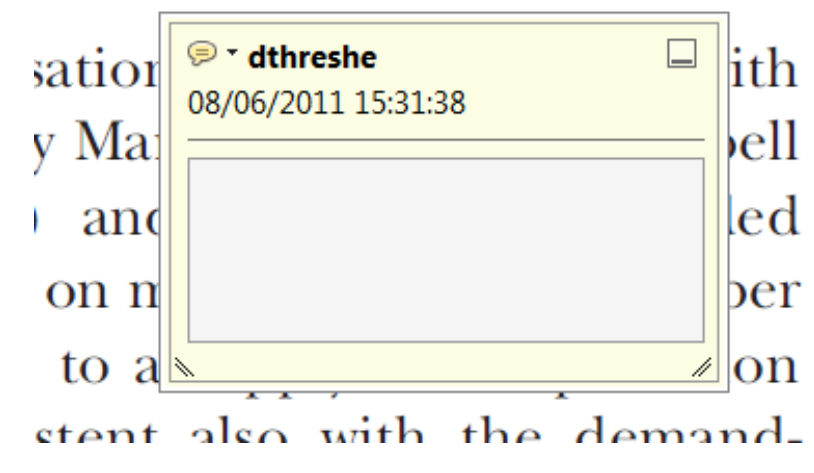

2. Strikethrough (Del) Tool - for deleting text.

Thikes a red line through text that is to be deleted.

\section{How to use it}

- Highlight a word or sentence.

- Click on the Strikethrough (Del) icon in the Annotations section.

there is no room tor extra prohts al c ups are zero and the number of ret) values are not determined by Blanchard and Kiyotaki (1987), rfect competition in general equilil ts of aggregate demand and supply lassical framework assuming monol eon an evorenois number of firms

\section{Add sticky note Tool - for making notes at} specific points in the text.

Marks a point in the proof where a comment needs to be highlighted.

\section{How to use it}

- Click on the Add sticky note icon in the Annotations section.

- Click at the point in the proof where the comment should be inserted.

- Type the comment into the yellow box that appears.

lallu allu suppiy silucks. hivst vi

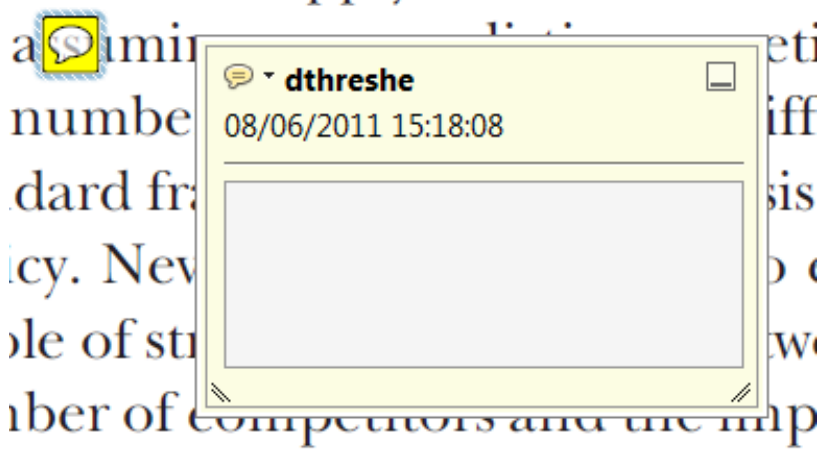

is that the structure of the secto 
5. Attach File Tool - for inserting large amounts of text or replacement figures.

Inserts an icon linking to the attached file in the appropriate pace in the text.

How to use it

- Click on the Attach File icon in the Annotations section.

- Click on the proof to where you'd like the attached file to be linked.

- Select the file to be attached from your computer or network.

- Select the colour and type of icon that will appear in the proof. Click OK.

E N D

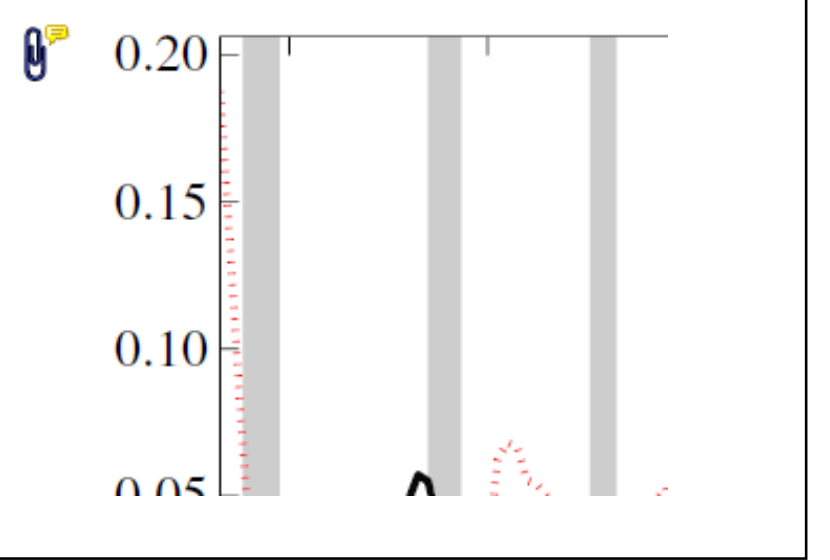

6. Add stamp Tool - for approving a proof if no corrections are required.

- Inserts a selected stamp onto an appropriate place in the proof

\section{How to use it}

- $\quad$ Click on the Add stamp icon in the Annotations section.

- $\quad$ Select the stamp you want to use. (The Approved stamp is usually available directly in the menu that appears).

- Click on the proof where you'd like the stamp to appear. (Where a proof is to be approved as it is, this would normally be on the first page).

of the Dusiness cycie, starting with the on perfect competition, constant ret

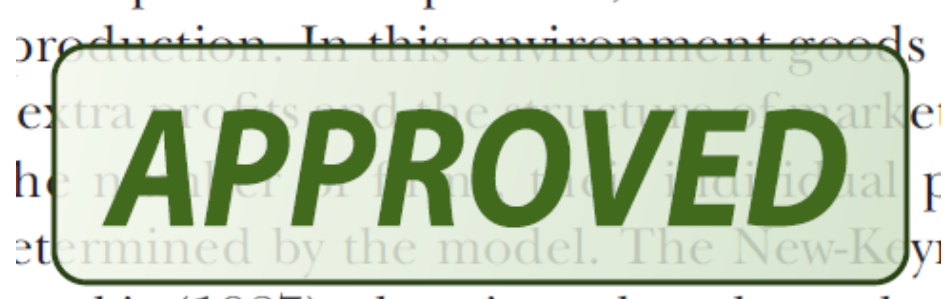

otaki (1987), has introduced produc general equilibrium models with nomin
- Drawing Markups

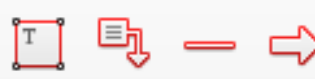

$0 \square \sqrt{6} D$

\section{How to use it}

- Click on one of the shapes in the Drawing Markups section.

- Click on the proof at the relevant point and draw the selected shape with the cursor.

- To add a comment to the drawn shape, move the cursor over the shape until an arrowhead appears.

- Double click on the shape and type any text in the red box that appears.
7. Drawing Markups Tools - for drawing shapes, lines and freeform annotations on proofs and commenting on these marks.

Allows shapes, lines and freeform annotations to be drawn on proofs and for comment to be made on these marks.

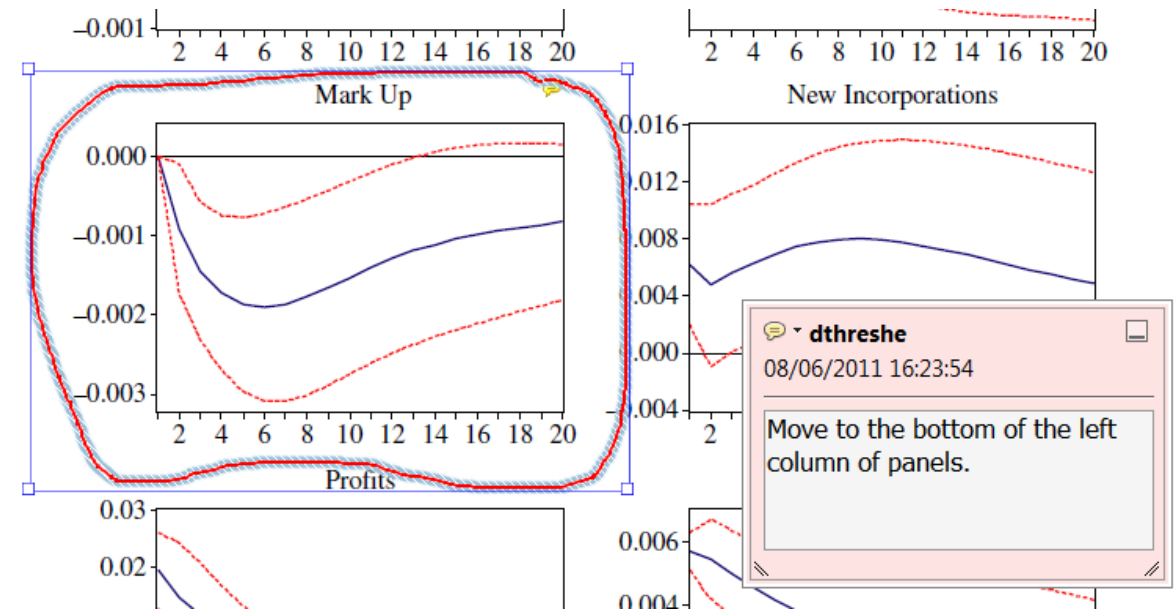

For further information on how to annotate proofs, click on the Help menu to reveal a list of further options:

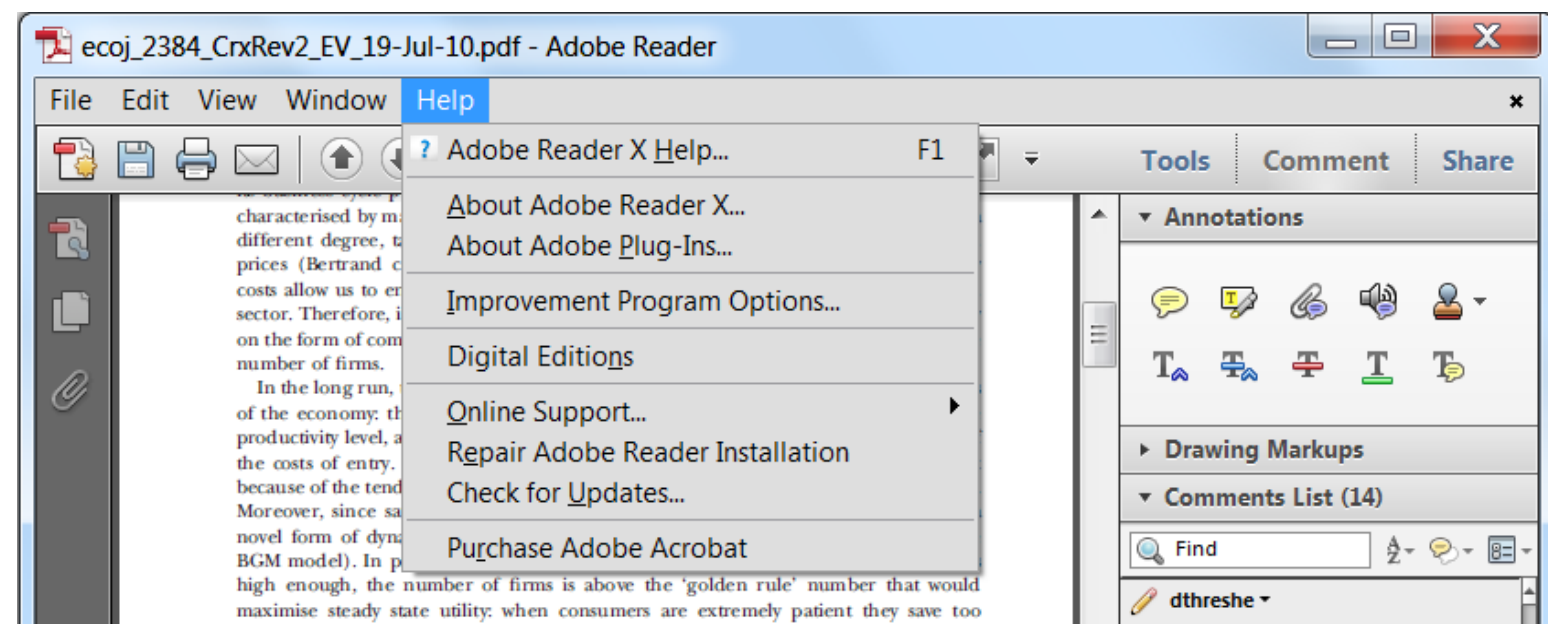

